\title{
Spillovers from U.S. Unconventional Monetary Policy and Its Normalization to Emerging Markets: A Capital Flow Perspective
}

\section{Sangwon Suh*, Byung-Soo Koo**}

The views expressed herein are those of the authors and do not necessarily reflect the official views of the Bank of Korea. When reporting or citing this paper, the authors' names should always be explicitly stated.

\footnotetext{
* Corresponding Author. Professor, School of Economics, Chung-Ang University; E-mail: ssuh@cau.ac.kr. ** Junior Economist. Daegu-Gyeongbuk Branch, Bank of Korea; E-mail: kbs@bok.or.kr.
}

The authors are grateful for helpful comments from Chanho Park, Daejung Yang, Jeong Wook Lee, Chung Hwa Kim. The first author is grateful for the financial support from the Bank of Korea; however, the views expressed herein are those of the authors and do not necessarily reflect those of the Bank of Korea. 


\section{Contents}

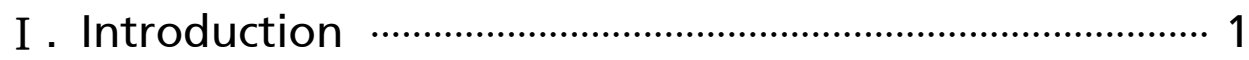

II . Methodology …………………………………………... 4

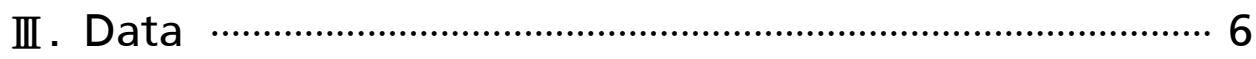

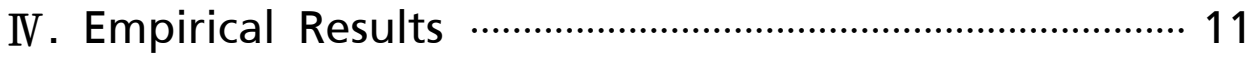

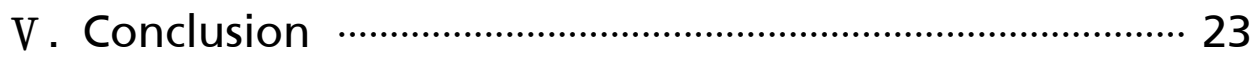

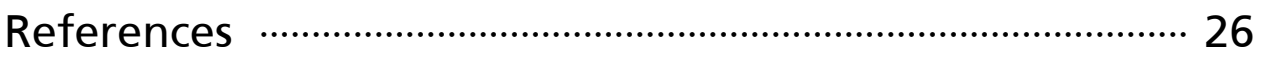




\section{Spillovers from U.S. Unconventional Monetary Policy and Its Normalization to Emerging Markets: A Capital Flow Perspective}

Policy makers employed unconventional monetary policy (UMP) tools to respond to the recent global financial crisis in the U.S. and other advanced economies, and the UMP is about to be normalized. In this paper, we try to quantitiatively assess the effects of the UMP and its normalization on capital flows to emerging market economies. We find that the UMP significantly affected capital flows on average. The effects of the normalization are closely related with the effects of the UMP. Importantly, the larger the capital inflows due to the UMP, the larger the capital outflows due to the normalization. Moreover, policy makers need to be careful of a potential risk of unexpected capital outflows (exceeding the expected ones) during an uncertain period whose size tends to be proportional to the size of the previous capital inflows.

Keywords: Capital flows, Unconventional monetary policy, Emerging markets, Cross-border borrowings

JEL classification: F37, F42, G15, G18 


\section{I . Introduction}

Recent global financial crisis (GFC) has begun in the U.S. 2007/2008 and then spread not only to advanced economies but also to emerging market countries. To respond to the GFC, the U.S. policy makers utilized a policy mix of fiscal stimulus and monetary easing in an unprecedented and aggressive manner. In particular, the monetary policy maker implemented not only de facto zero policy interest rate but also a series of the so-called "quantitative easing" (QE) measures. By the help of these active policy responses, the U.S. economy started to recover from a long period of recession. In May 2013, the then Federal Reserve chairman announced to "normalize" the Fed's unconventional monetary policy (UMP) in a near future.1) As of 2015, other important economies such as the Eurozone economy, China, and Japan do not seem to move in tandem with the U.S. economy. Despite this decoupling phenomenon, the "normalization" is expected to be implemented from 2015.2) This normalization process has been an issue of great interest not only for the U.S. economy but also for other countries since its announcement.

The UMP with several QE measures have exerted significant impacts not only on the U.S. economy but also on other economies. From the perspective of capital flows (CFs), many emerging market economies (EMEs) have received a significant amount of capital inflows during the UMP period. Now, the recipient EMEs regard the normalization process as a reversal of the UMP and are concerned over its potential negative impacts to be brought. Their concerns are legitimate for several reasons. First, large scale capital inflows may contribute to economic imbalances and latent risks of recipient countries. ${ }^{3)}$ Second, if capital outflow size

1) Federal Reserve Chairman Ben Bernanke testified to Congress on May 22, 2013, that the Fed would likely start slowing that is, tapering the pace of its bond purchases later in the year, conditional on continuing good economic news. At June 19 press conference, the Chairman optimistically described economic conditions and again suggested that asset purchases might be reduced later in 2013: "[T] Committee currently anticipates that it would be appropriate to moderate the monthly pace of purchases later this year."

2) For example, Federal Reserve Chair Jannet Yellen said at Rhode Island speech on May 22, 2015 that "[I]f the economy continues to improve as I expect, I think it will be appropriate at some point this year to take the initial step to raise the federal funds rate target and begin the process of normalizing monetary policy."

3) For example, Reinhart and Reinhart (2008) argue that "[B]onanzas are no blessing for advanced or emerging market economies. In the case of the latter, capital inflow bonanzas are associated with a higher likelihood of economic crises (debt defaults, banking, inflation and currency crashes)." 
is proportional to the immediately previous capital inflow size, then capital inflow size during the UMP period may be a predictor to the size of risks to which recipient countries are exposed.4) Third, many EMEs which are decoupled with the U.S. economy may be vulnerable to negative impacts from significant capital outflow shocks.

Even though we may confidently conjecture a qualitative direction of the influences of the normalization process, it may not be an easy task to estimate the quantitative size of the influences which, however, would be an essential input for policy decision-making. In this paper, we try to estimate the quantitative size of the influences of the normalization of the UMP from the perspective of EMEs. To this end, we first classify CFs into three types: cross-border borrowings, bond-related CFs, and international equity investments. We then separately set up behavioral models for CFs to EMEs for each type of CFs. We estimate the models and use the results to estimate not only the effects of the UMP on the CFs but also the effects of the normalization. For better estimation, we take into account both the so-called "push" and "pull" CF factors. We also account for not only direct but also indirect effects of the UMP (and its normalization) on CFs. We examine the recent experience after the first normalization announcement as well.

We find that the UMP significantly affected CFs to EMEs on average; however, the effect size varies across countries and across CF types. The effect size of the UMP is great for both cross-border borrowings and bond channels and relatively little for equity channel. Importantly, the effects of the normalization are closely related with the effects of the UMP, which has a profound policy implication. The larger the capital inflows due to the UMP, the larger the capital outflows due to the normalization. Moreover, policy makers need to be careful of a potential risk of unexpected capital outflows (exceeding the expected ones) during an uncertain period whose size tends to be proportional to the size of the previous capital inflows.

Although related issues have been extensively studied recently, this paper differs from existing literature in several respects. First, CFs have been extensively analyzed in the literature. Confining to only recent studies, Koepke (2015)

4) Relatedly, Agosin and Huaita (2012) find an "overreation" in capital flows that a surge in capital flows can predict future sharp contractions in capital flows. 
provided a survey on the various determinants of CFs. Rey (2013) evidenced the existence of the so-called global financial cycle which refers to the co-movements among different types of CF and across countries. Bruno and Shin (2015) provided a simple theoretical model for cross-border banking and the associated empirical analysis. McCauley, McGuire, and Sushko (2015) set up behavioral models for cross-border banking and offshore dollar bond growth. While existing studies on CFs have mainly focused on finding the drivers of CFs, this paper has more interest in how much the UMP (the normalization) had (will have) quantitative impacts on CFs.

Second, several works have studied the spillover effects of the UMP. For example, Bauer and Neely (2014) utilized term structure models to analyze the effects of the UMP on long- term yields. Neely (2015) used an event study method to examine the effects on long-term yields and exchange rates. Chen, Filardo, He, and Zhu (2015) employ a global vector error correction model (GVECM) to study the effects of the UMP on macro-economy. International institutions such as IMF also provided comprehensive analyses of the UMP (see for example, IMF (2013a, 2013b)). While Bauer and Neely (2014) and Neely (2015) focus on the spillover effects of the UMP on market prices (such as long-term yields and exchange rates) and Chen, Filardo, He, and Zhu (2015) focus on macro-economy, this paper focuses on CFs. Exogenous shocks may have only temporary effects or long-lasting effects on market prices. Presumably, the exogenous shocks may tend to have long-lasting effects and eventually affect macro-economy only when they are accompanied with ensuing CF changes. In this respect, CFs may be regarded as an intermediate channel from exogenous shocks to macro-economy, and thus it is meaningful to focus on CFs as this paper does. ${ }^{5)}$

Third, this paper is more closely related to few works which attempted to quantify the effects of the UMP on CFs to EMEs by using EM-dedicated investment fund-level data (see, for example, Fratzscher, Duca, and Straub

5) Relatedly, there exists a large literature on the relationship between CFs and economic growth. Examples include Arteta, Eichengreen and Wyplosz (2001), Eichengreen (2001), Henry (2007), Reinhart and Reinhart (2008), BIS (2009), Kose, Prasad, Rogoff, and Wei (2009), Vo (2009), Choong, Baharumshah, Yusop, and Habibullah (2010), Aizenman, Jinjarak, and Park (2013), Caballero (2014), and Yoon and Kim (2015) among others. 
(2013) and Koepke (2013)). Unlike this paper, these works did not cover cross-border bank borrowings. Moreover, the fund-level data also have a limited coverage. However, such analyses using micro data with high frequencies may complement the results of this paper.

Fourth, some works examined the experiences after the first announcement of the normalization, so-called "taper tantrum" (TT). For example, Avdjiev and Takats (2014) studied the taper tantrum phenomenon in terms of cross-border borrowings. Eichengreen and Gupta (2015) examined the effects of TT on exchange rates, foreign reserves, and equity return and tried to analyze who was hit and why. This paper provides a comprehensive analysis not only by examining the TT experiences but also by estimating the effects of the UMP and the normalization.

The rest of this paper is organized as follows. In the next section, we present our methodology for quantitatively analyzing the effects of the UMP and the normalization. We introduce behavioral models for CFs and explain how to account for direct and indirect effects of the UMP and of the normalization. In Section 3, we explain the data to be used for our analysis. We separately provide empirical results for each type of CFs in Section 4. We present estimation results, the estimated effects of the UMP as well as the normalization process. We conclude in Section 5.

\section{II . Methodology}

In this section, we first introduce behavioral models for CFs. We then explain how to account for the indirect effects of the UMP and its normalization on CFs. Lastly, we explain how to estimate the total effects of the UMP and the normalization policy on CFs.

We have $I$ EMEs in our sample $(i=1, \ldots, I)$. We consider three types of CFs: cross-border borrowings $(j=l)$, bond-related CFs $(j=b)$, and international equity investments $(j=e)$ For type $j$ CFs, the determinants of CFs are classified into three kinds of explanatory variables: $Q_{j}, Z_{j}$, and $X_{i, j}$. We introduce two kinds of 
common variable vectors in order to appropriately assess policy effects. The UMP is proxied by $Q_{j}$, a $M_{j}$-vector of the UMP-related variables which are assumed to be common with countries but to have differential effects across countries. The other common variables are indicated by $Z_{j}$, a $N_{j}$-vector which consists of the so-called "push" factors. A $K_{j}$-vector $X_{i, j}$ indicates country $i$-specific explanatory variables which comprise of the so-called "pull" factors. To account for the potential difference in the dynamics, we separately set up our behavioral models for each type of CFs by employing a panel regression model with fixed effects. That is, the type $j$ CF into country $i$ at time $t, y_{i, j, t}$, is modelled as:

$$
y_{i, j, t}=\alpha_{i, j, 0}+\alpha^{\prime}{ }_{j, 1} X_{i, j, t}+\alpha^{\prime}{ }_{i, j, 2} Q_{j, t}+\alpha^{\prime}{ }_{j, 3} Z_{j, t}+\epsilon_{i, j, t},
$$

where $\epsilon_{i, j, t}$ indicates a disturbance term, and coefficient vectors $\alpha_{j, 1}, \alpha_{i, j, 2}$, and $\alpha_{j, 3}$ have conforming dimensions.

The UMP not only directly affects CFs with coefficients $\alpha_{i, j, 2}$ but may also indirectly affect CFs via other explanatory variables. To assess these indirect impacts, we additionally set up simple behavioral equations for the effects of the UMP on other explanatory variables:

$$
\begin{gathered}
x_{i, j, k, t}=\beta_{i, j, k, 0}+\beta_{i, j, k, 1}^{\prime} Q_{j, t}+u_{i, j, k, t}, \quad k=1, \ldots, K_{j}, \quad i=1, \ldots, I, \\
z_{j, n, t}=\gamma_{j, n, 0}+\gamma_{j, n, 1}^{\prime} Q_{j, t}+v_{j, n, t}, \quad n=1, \ldots, N_{j},
\end{gathered}
$$

where $x_{i, j, k, t}$ is the $k$-th element of $X_{i, j, t}$, and $z_{j, n, t}$ is the $n$-th element of $Z_{j, t} \cdot{ }^{6}$

To estimate the effects of the UMP, we first construct a hypothetical path $Q_{j, t}^{h}$ of the UMP-related variables under the assumption of no-UMP. We then calculate the hypothesized values of other explanatory variables $X_{i, j, t}$ and $Z_{j, t}$ under the no-UMP assumption as:

$$
\begin{gathered}
x_{i, j, k, t}^{h}=x_{i, j, k, t}-\hat{\beta}_{i, j, k, 1}^{\prime}\left(Q_{j, t}-Q_{j, t}^{h}\right), \quad k=1, \ldots, K_{j}, \quad i=1, \ldots, I, \\
z_{j, n, t}^{h}=z_{j, n, t}-\hat{\gamma}_{j, n, 1}^{\prime}\left(Q_{j, t}-Q_{j, t}^{h}\right), \quad n=1, \ldots, N_{j},
\end{gathered}
$$

6) In (2) and (3), other potential explanatory variables are ignored for simplicity. 
where $\hat{\beta}_{i, j, k, 1}^{\prime}$ and $\hat{\gamma}_{j, n, 1}$ are the estimates of the corresponding coefficient vectors, respectively.

By taking together the direct as well as indirect effects of the UMP on the CFs, we calculate the hypothesized values of the CFs, $y_{i, j, t}^{h}$, and the total effects of the UMP on the CFs, $y_{i, j, t}-y_{i, j, t}^{h}$, as follows:

$$
\begin{aligned}
& y_{i, j, t}^{h}=y_{i, j, t}-\hat{\alpha}_{j, 1}^{\prime}\left(X_{i, j, t}-X_{i, j, t}^{h}\right)-\hat{\alpha}_{i, j, 2}^{\prime}\left(Q_{j, t}-Q_{j, t}^{h}\right)-\hat{\alpha}_{j, 3}^{\prime}\left(Z_{j, t}-Z_{j, t}^{h}\right), \\
& y_{i, j, t}-y_{i, j, t}^{h}=\hat{\alpha}_{j, 1}^{\prime}\left(X_{i, j, t}-X_{i, j, t}^{h}\right)+\hat{\alpha}_{i, j, 2}^{\prime}\left(Q_{j, t}-Q_{j, t}^{h}\right)+\hat{\alpha}_{j, 3}^{\prime}\left(Z_{j, t}-Z_{j, t}^{h}\right),
\end{aligned}
$$

where $\hat{\alpha}_{j, 1}, \hat{\alpha}_{i, j, 2}$, and $\hat{\alpha}_{j, 3}$ are the estimates of the corresponding coefficient vectors, respectively.

Similarly, we can gauge the effects of the "normalization" policy on the CFs to EMEs byconstructing a hypothetical path $Q_{j, t+m}^{n}$ of the UMP-related variables under the assumption of the "normalization" policy at time $t+m$ (with a horizon of $m$ periods). That is, the effects of the "normalization" policy on the CFs, $y_{i, j, t+m}^{u}-y_{i, j, t+m}^{n}$, is measured as:

$$
y_{i, j, t+m}^{u}-y_{i, j, t+m}^{n}=\hat{\alpha}_{j, 1}^{\prime}\left(X_{i, j, t+m}^{u}-X_{i, j, t+m}^{n}\right)+\hat{\alpha}_{i, j, 2}^{\prime}\left(Q_{j, t+m}^{u}-Q_{j, t+m}^{n}\right)+\hat{\alpha}_{j, 3}^{\prime}\left(Z_{j, t+m}^{u}-Z_{j, t+m}^{n}\right),
$$

where superscripts $u$ and $n$ indicate the UMP assumption and the "normalization" policy assumption, respectively.

\section{Data}

In this section, we explain the data to be used for our analysis. Following Avdjiev and Takáts (2014), we select 39 EMEs as our sample countries, based on the outstanding amounts of cross-border borrowings and data availability. ${ }^{7)}$ Our sample countries include Argentina, Brazil, Bulgaria, Chile, China, Chinese

7) Avdjiev and Takáts (2014) selected 35 EMEs whose cross-border bank borrowings exceeded \$10 billion at the end of 2013. 
Taipei, Colombia, Costa Rica, Croatia, Czech Republic, Egypt, Hungary, India, Indonesia, Israel, Jordan, Kazakhstan, Korea, Lithuania, Malaysia, Mexico, Morocco, Nigeria, Pakistan, Peru, Philippines, Poland, Qatar, Romania, Russia, Saudi Arabia, South Africa, Thailand, Turkey, Ukraine, United Arab Emirates, Uruguay, Venezuela, and Vietnam.

To account for potential differences in the dynamics, we will separately examine three types of CFs: cross-border borrowings, bond-related CFs, and international equity investments. For each type of CFs, we first construct outstanding liabilities and then measure $\mathrm{CFs}$ as the difference between two consecutive liabilities. ${ }^{8)}$ The cross-border outstanding borrowings are measured by the cross-border loans of BIS-reporting banks on all borrowers (Table 7A in the BIS Locational Statistics.) This BIS locational statistics data are compiled according to the country of residence of the reporting banks. Both the bond-related outstanding liabilities and the equity-related outstanding liabilities are constructed by taking the corresponding IMF IIP data as of the end of 2005 and by accumulating the corresponding IMF BOP data forward and by decumulating the flow data backward.9)

All data are quarterly. The whole sample periods are 1995/Q4 - 2014/Q4 for cross-border borrowings, 1993/Q1 - 2014/Q4 for bond-related CFs, and 1995/Q1 2014/Q4 international equity investments. For the purpose of comparison and summarizing, we introduce three sub-periods: pre-GFC period (2003/Q1 2008/Q4), UMP period (2009/Q1 - 2013/Q1), and TT period (2013/Q2 - 2014/Q4).

Figure 1 shows the time trends of the sum of the outstanding balances of the 39 sample EMEs for each type of CFs during the sample period. Cross-border borrowings claim the first place, bond-related CFs the next and equity-related CFs the last, showing the outstanding balances of 2.6, 2.2, and 1.9 trillion U.S. dollar as of 2014/Q4, respectively. The dynamics of the three types of CFs look different. Cross-border borrowings significantly declined after the outbreak of GFC and also

8) Noteworthily, we focus only on liability-side CFs and deliberately ignore asset-side CFs in order to make our measures be more consistent with the so-called CF "surge" and "sudden stops."

9) The current IMF IIP data are based on the IMF BMP6 and start from the end of 2005. It is worthwhile to note that these outstanding liabilities exclude market valuation effects. 
Figure 1: Capital Flows to Emerging Market Economies

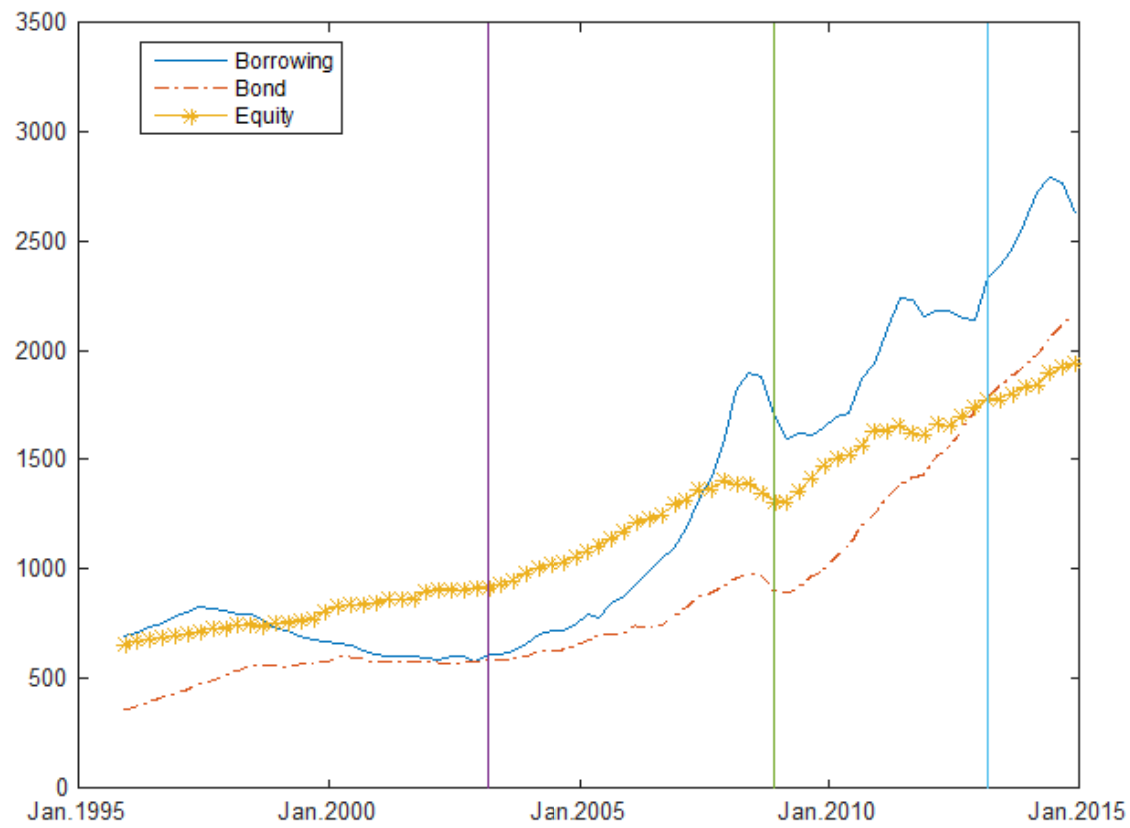

Notes: 1) The sum of the outstanding balances of the 39 sample EMEs for each of three types of CFs.

2) The sample period is from 1995/Q4 to $2014 / \mathrm{Q} 4$.

3) Three vertical lines indicate 2003/Q1, 2008/Q4 and 2013/Q1, respectively to denote three sub-periods: pre-GFC period, UMP period and $\Pi$ period.

4) Values are measured in billion U.S. dollar.

showed a short-lived stagnation before the taper tantrum event. Unlike cross-border borrowings, bond-related CFs has shown a rapid growth since 2010. Equity-related CFs significantly dropped during the GFC and then showed a steady growth path again.

Panel A of Table 1 shows that cross-border borrowings, bond-related CFs, and equity-related CFs to EMEs recorded amounts of 2.0, 1.6, and 1.0 trillion U.S. dollar, respectively, during 2003/Q1 - 2014/Q4. While cross-border borrowings grew more faster than bond-related CFs during the pre-GFC period, the opposite occurred during both the UMP and the TT periods. Panel B of Table 1 demonstrates that the average annual bond-type CFs to EMEs have grown at a faster pace during the post-GFC periods than during the pre-GFC period. 
Table 1: Capital Flows to EMEs and Their Correlation

\begin{tabular}{|c|c|c|c|c|c|}
\hline Type of CF & \multicolumn{2}{|c|}{ Whole } & Pre-GFC & UMP & TT \\
\hline \multicolumn{6}{|c|}{ A. Total CFs to EMEs (billion USD) } \\
\hline \multicolumn{2}{|l|}{ Borrowings } & $2,009.9$ & $1,090.0$ & 624.7 & 295.2 \\
\hline \multicolumn{2}{|l|}{ Bond } & $1,579.0$ & 318.6 & 884.6 & 375.8 \\
\hline \multicolumn{2}{|l|}{ Equity } & $1,021.4$ & 392.3 & 466.6 & 162.5 \\
\hline \multicolumn{6}{|c|}{ B. Annual CFs to EMEs (billion USD) } \\
\hline \multicolumn{2}{|l|}{ Borrowings } & 171.1 & 189.6 & 147.0 & 168.7 \\
\hline \multicolumn{2}{|l|}{ Bond } & 134.4 & 55.4 & 208.1 & 214.7 \\
\hline Equity & & 86.9 & 68.2 & 109.8 & 92.9 \\
\hline \multicolumn{6}{|c|}{ C. Percentile of bilateral correlations } \\
\hline \multirow[t]{3}{*}{ Borrowings } & $25 \%$ & 0.416 & 0.433 & -0.438 & -0.466 \\
\hline & $50 \%$ & 0.708 & 0.874 & 0.186 & 0.068 \\
\hline & $75 \%$ & 0.856 & 0.954 & 0.725 & 0.508 \\
\hline \multirow[t]{3}{*}{ Bond } & $25 \%$ & 0.435 & 0.123 & 0.527 & 0.000 \\
\hline & $50 \%$ & 0.835 & 0.672 & 0.827 & 0.566 \\
\hline & $75 \%$ & 0.936 & 0.845 & 0.939 & 0.846 \\
\hline \multirow[t]{3}{*}{ Equity } & $25 \%$ & -0.172 & 0.000 & -0.130 & -0.422 \\
\hline & $50 \%$ & 0.643 & 0.740 & 0.450 & 0.429 \\
\hline & $75 \%$ & 0.865 & 0.911 & 0.784 & 0.816 \\
\hline
\end{tabular}

Notes: 1) The average annual CFs to EMEs (Panel B) for each of three types of CFs and for various periods.

2) Panel $C$ presents the $25 \%, 50 \%$ and $75 \%$ percentiles of the bilateral correlations of all possible pairs of EMEs.

Figure 2 illustrates three types of CFs to individual EMEs during the whole sample period. Relative importances of CF types differ across countries. Cross-border borrowings have a more relative importance for China, India, and Turkey, while bond-related CFs is more important for Mexico, Korea, and Poland. Panel C of Table 1 presents the $25 \%, 50 \%$, and $75 \%$ percentiles of the bilateral correlations of all possible pairs of EMEs for each type of CFs and for various periods. Cross-border borrowings showed close co-movements during the pre-GFC period; however, the co-movements became loose during the post-GFC periods. By contrast, bond-related CFs showed close co-movements not only during the pre-GFC period but also during the UMP period. On the other hand, equity-related CFs showed a wide range of correlations among EMEs and the co-movements became loose during the post-GFC periods as well. We will try to 
Figure 2: Capital Flows to Individual EMEs

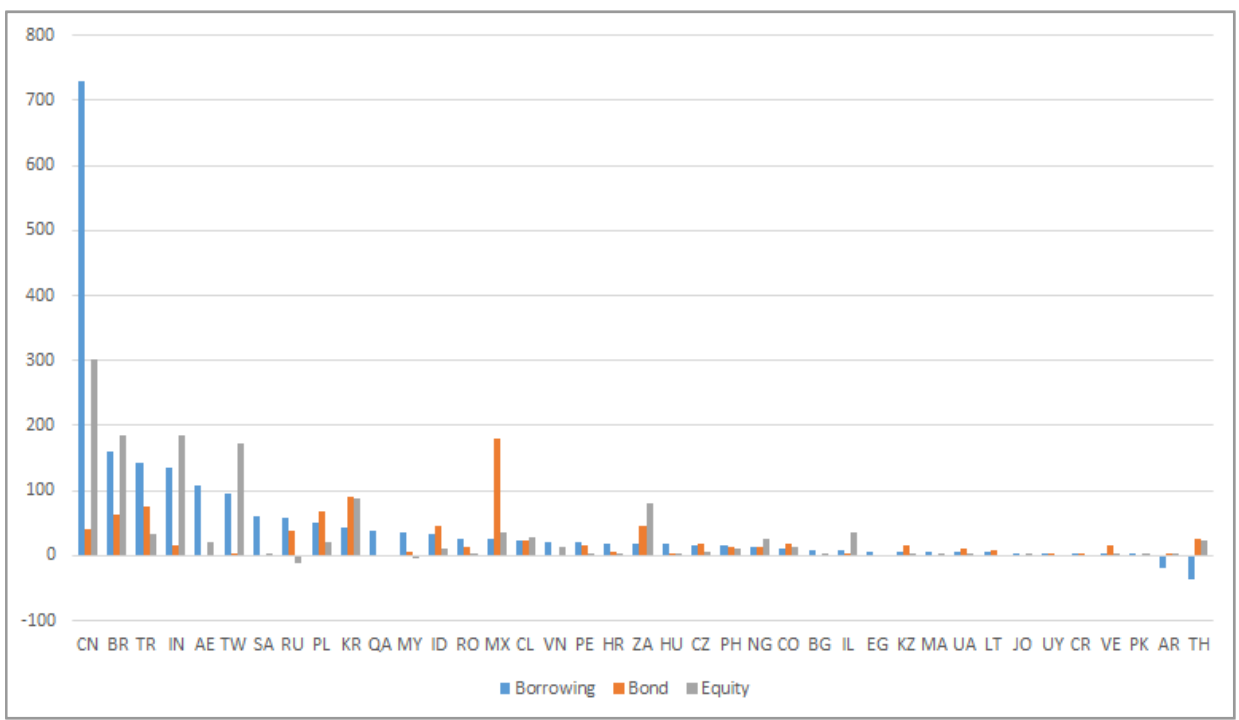

Notes: 1) The sample period is from 1995/Q4 to 2014/Q4.

2) Values are measured in billion U.S. dollar.

account for these differences in the dynamics of CFs according to the types, countries, and periods in our analysis.

In order to select relevant explanatory variables, we refer to previous studies such as Rey (2013), McCauley, McGuire, and Sushko (2015), Bruno and Shin (2015), Koepke (2015), and Chen, Filardo, He, and Zhu (2015). We choose as the UMP-related variables the U.S. term spread and the U.S. corporate spread, following Chen, Filardo, He, Zhu (2015). We also considered the Fed total assets as a potential UMP-related variable. In addition, we include sovereign credit ratings for all countries and commodity price changes only for commodity-exporting countries.10) Table 2 shows the list of the explanatory variables to be considered for each type of CFs.

10) We transform the sovereign credit ratings into a numeric variable with equal interval between notches. We define a country as commodity-exporting one if its commodity exports exceed $50 \%$ of the merchandise exports or $20 \%$ of its GDP, based on 2012 UNCTAD statistics. Our sample includes 18 commodity-exporting countries. 


\section{$11 \quad$ BOK Working Paper No. 2016-4}

\section{Table 2: List of Explanatory Variables}

\begin{tabular}{|c|c|c|c|c|}
\hline \multirow[t]{2}{*}{ Type } & \multirow{2}{*}{$\begin{array}{c}\text { Explanatory } \\
\text { Variables }\end{array}$} & \multicolumn{3}{|c|}{ Capital Flows } \\
\hline & & Borrowings & Bond & Equity \\
\hline \multirow[t]{4}{*}{ UMP-related } & U.S. term spread & 0 & 0 & 0 \\
\hline & U.S. corporate spread & 0 & 0 & O \\
\hline & Fed total assets & 0 & 0 & 0 \\
\hline & Deviations from Taylor rule & O & O & O \\
\hline \multirow[t]{6}{*}{ Common "push" factor } & VIX & O & & O \\
\hline & USD NEER & O & O & O \\
\hline & World GDP growth & 0 & 0 & O \\
\hline & Commodity price & O & O & O \\
\hline & MOVE & & O & \\
\hline & MSCI EM equity return & & & O \\
\hline \multirow[t]{9}{*}{ Country-specific "pull" factor } & Policy rate & 0 & 0 & 0 \\
\hline & GDP growth & 0 & 0 & 0 \\
\hline & Domestic currency NEER & 0 & O & O \\
\hline & Debt-to-GDP ratio & 0 & O & 0 \\
\hline & CA-to-GDP ratio & O & O & O \\
\hline & CDS premium & O & O & O \\
\hline & Credit ratings & 0 & 0 & O \\
\hline & Yield difference & & 0 & \\
\hline & Domestic equity return & & & O \\
\hline
\end{tabular}

Notes: 1) U.S. term spread refers to the difference between 10 year and three months Treasury yields.

2) U.S. corporate spread refers to the difference between AAA-rated U.S. corporate yields and the Federal Fund Rate.

3) NEER indicates the nominal effective exchange rate.

4) Commodity price refers to the Bloomberg Commodity Index.

5) MOVE indicates the Merrill Option Volatility Expectations Index of Treasury bond yields.

6) CA refers to capital accounts.

7) Credit ratings reflect sovereign credit ratings averaged from top three rating agencies.

8) Yield difference refers to the difference between 10-year domestic government bond yields and U.S. Treasury bond yields.

\section{Empirical Results}

In this section, we separately provide empirical results for each type of CFs. The empirical results include estimation results, the effects of the UMP and its normalization. 


\section{Estimation results}

We use log difference as dependent variables for each type of CF outstanding liabilities. We first run a panel regression of each type of CFs on a single explanatory variable to see whether the explanatory variable has a correct sign or not. To avoid potential endogeneity, we use one-period-lagged explanatory variables for all regressions. We then exclude the explanatory variables with incorrect sign in the single variable regressions. Next, we run a panel regression (1) with various combinations of multiple explanatory variables. Table 3 shows the results of panel regression (1) with the restriction of a common coefficient on the UMP-related variable for the ease of exposition. ${ }^{11)}$ The regression is run from the beginning of the sample period to the end of the UMP period, and the TT period is reserved for out-of-sample forecasting. ${ }^{12)}$

The U.S. corporate spread, the U.S. policy rate, VIX, commodity price, and debt-to-GDP ratio negatively affect cross-border borrowings to EMEs while world GDP growth, domestic GDP growth and sovereign credit ratings positively affect. For bond-related CFs of EMEs, the U.S. policy rate, debt-to-GDP ratio, commodity price, and MOVE are negatively related. The U.S. corporate spread, VIX, and commodity price negatively affect equity-related CFs to EMEs while domestic GDP growth, sovereign credit ratings, and domestic equity return positively affect them.

We conduct a formal test for out-of-sample forecasting to assess a relative performance of the behavioral models. In particular, we examine whether the proposed behavioral models have better out-of-sample forecasting performances against a simple random walk (RW) prediction model. We use the estimation results of the behavioral models with the sample data before the TT period to produce out-of-sample forecasts over the TT period. On the other hand, the RW

11) The results of panel regression (1) with differentiated coefficients on the UMP-related variable are also available upon request.

12) We run the regression from $2005 / \mathrm{Q} 1$ for bond-related CFs, based on the belief that bond market development in EMEs is only a recent phenomenon and it would be more relevant to confine our analysis to a recent period. 


\section{Table 3: Estimation Results}

\begin{tabular}{|c|c|c|c|c|c|c|c|c|}
\hline \multirow[t]{2}{*}{ Variables } & \multicolumn{3}{|c|}{ Borrowings } & \multicolumn{2}{|c|}{ Bond } & \multicolumn{3}{|c|}{ Equity } \\
\hline & Coefficient & t-value & & Coefficient & t-value & Coefficient & t-value & \\
\hline CreditSp & -0.0045 & -2.31 & ** & & & -0.0021 & -1.65 & * \\
\hline FFR & -0.0018 & -1.14 & & -0.0020 & -0.85 & & & \\
\hline VIX & -0.0013 & -3.98 & $* * *$ & & & -0.0007 & -2.74 & *** \\
\hline ComPr*Dum & -0.0290 & -1.58 & & -0.0654 & $-2.35^{* *}$ & -0.0343 & -2.06 & $* *$ \\
\hline MOVE & & & & -0.0004 & $-3.87^{* * *}$ & & & \\
\hline Wgrowth & 0.0019 & 0.94 & & & & & & \\
\hline GDP & 0.0019 & 3.25 & $* * *$ & & & 0.0008 & 1.41 & \\
\hline Debt/GDP & -0.0016 & -4.19 & *** & -0.0020 & -1.53 & & & \\
\hline$C R$ & 0.0092 & 3.55 & $* * *$ & & & 0.0048 & 1.92 & $*$ \\
\hline StockRet & & & & & & 0.0003 & 3.09 & *** \\
\hline Observations & 2367 & & & 992 & & 1919 & & \\
\hline $\mathrm{R}^{2}$ & 0.0667 & & & 0.0205 & & 0.0215 & & \\
\hline Wald F & 20.72 & & & 5.00 & & 6.88 & & \\
\hline ( $p$-value) & 0.0000 & & & 0.0006 & & 0.0000 & & \\
\hline
\end{tabular}

Notes: 1) This table shows the estimation results of panel regression (1) with the restriction of a common coefficient on the UMP-related variable, using the sample data until the UMP period.

2) 'CreditSp' indicates the U.S. corporate spread.

3) 'FFR' refers to the deviations from Taylor rule.

4) 'ComPr*Dum' indicates previous one-year commodity price index changes only for commodity-exporting countries.

5) 'Wgrowth' refers to the world GDP growth.

6) ' $C R$ ' indicates sovereign credit rating changes over the previous one-year.

7) 'StockRet' refers to domestic equity returns, respectively.

8) Statistical significance of $1 \%, 5 \%$ and $10 \%$ is market by ***, ** and *, respectively.

model takes the current value as the next period forecast. Table 4 shows the hypothesis testing results for out-of-sample forecasting performances, using Diebold and Mariano (1995) test. The suggested behavioral models turn out to have better out-of-sample forecasting than the RW model for all types of CFs.

\section{Effects of the UMP}

The effects of the UMP on CFs during the UMP period is estimated by combining the direct and the indirect effects as explained in Section 2.13) Like Chen, Filardo, He, Zhu (2015), we assume the U.S. corporate spread to increase 


\section{Table 4: Testing for Out-of-sample Forecasting Performance}

\begin{tabular}{|c|c|c|c|}
\hline & Borrowings & Bond & Equity \\
\hline RMSFE & 0.0054 & 0.0104 & 0.0082 \\
\hline RMSFE-RW & 0.0075 & 0.0201 & 0.0171 \\
\hline DM statistic & -2.5246 & -2.3638 & -1.2432 \\
\hline$p$-value & 0.0058 & 0.0090 & 0.1069 \\
\hline
\end{tabular}

Notes: 1) This hypothesis test is conducted to examine whether the proposed behavioral models have better out-of-sample forecasting performances against a simple random walk (RW) prediction model. Out-of-sample forecasts are compared over the $\Pi T$ period.

2) Diebold and Mariano (1995) tests are employed for the test.

3) Root-mean-squared forecasting errors of the suggested behavioral model (RMSFE) and of the RW model (RMSFE-RW) are provided.

by 15 bps every quarter during the UMP period (i.e., 255 bps in total) under a no-UMP scenario for a counterfactual exercise to estimate the effects of the UMP. In addition, we assume that the FFR is set equal to Taylor rule.

Based on these scenarios for the no-UMP, Figure 3 shows the effects of the UMP on cross- border borrowings by EMEs during the UMP period, contrasted with their actual changes. Cumulative effects of the UMP on cross-border borrowings by EMEs range from $31 \%$ to $238 \%$ (with average of $93 \%$ ), while the actual changes range from $-64 \%$ to $351 \%$ (with average of $32 \%$ ). Interestingly, there exists a negative relationship between the estimated effects of the UMP on cross-border borrowings by EMEs and the actual changes. It implies that factors other than the UMP significantly affect CFs in an opposite direction.

Figures 4 and 5 show the results for bond-related CFs by EMEs and of equity-related CFs to EMEs, respectively. Cumulative effects of the UMP on bond-related CFs by EMEs range from $-2 \%$ to $171 \%$ (with average of $30 \%$ ), while the actual changes range from $-43 \%$ to $850 \%$ (with average of $142 \%$ ). Compared to the cases of borrowings and bonds, the UMP exerted relatively small impacts on equity-related CFs. Cumulative effects of the UMP on equity-related CFs to EMEs range from $1 \%$ to $45 \%$ (with average of $9 \%$ ), while the actual changes range from $-83 \%$ to $494 \%$ (with average of $51 \%$ ). Unlike the case of borrowings, the estimated

13) For the UMP-related variable, we replace individual coefficients with incorrect sign with zero in order to obtain reasonable results. 


\section{$15 \quad$ BOK Working Paper No. 2016-4}

Figure 3: Actual Changes vs. The Effects of the UMP during the UMP Period: Cross-border Borrowings

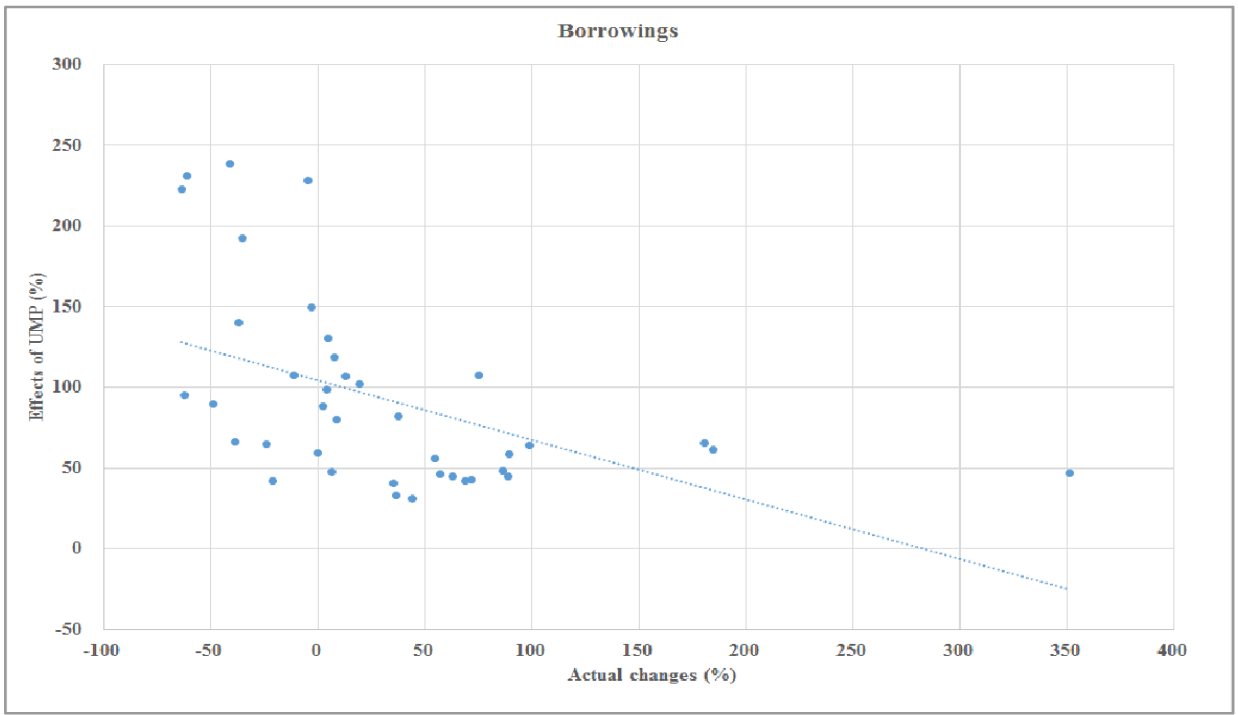

Note: The dotted line indicates the trend line.

Figure 4: Actual Changes vs. The Effects of the UMP during the UMP Period: Bond-related CFs

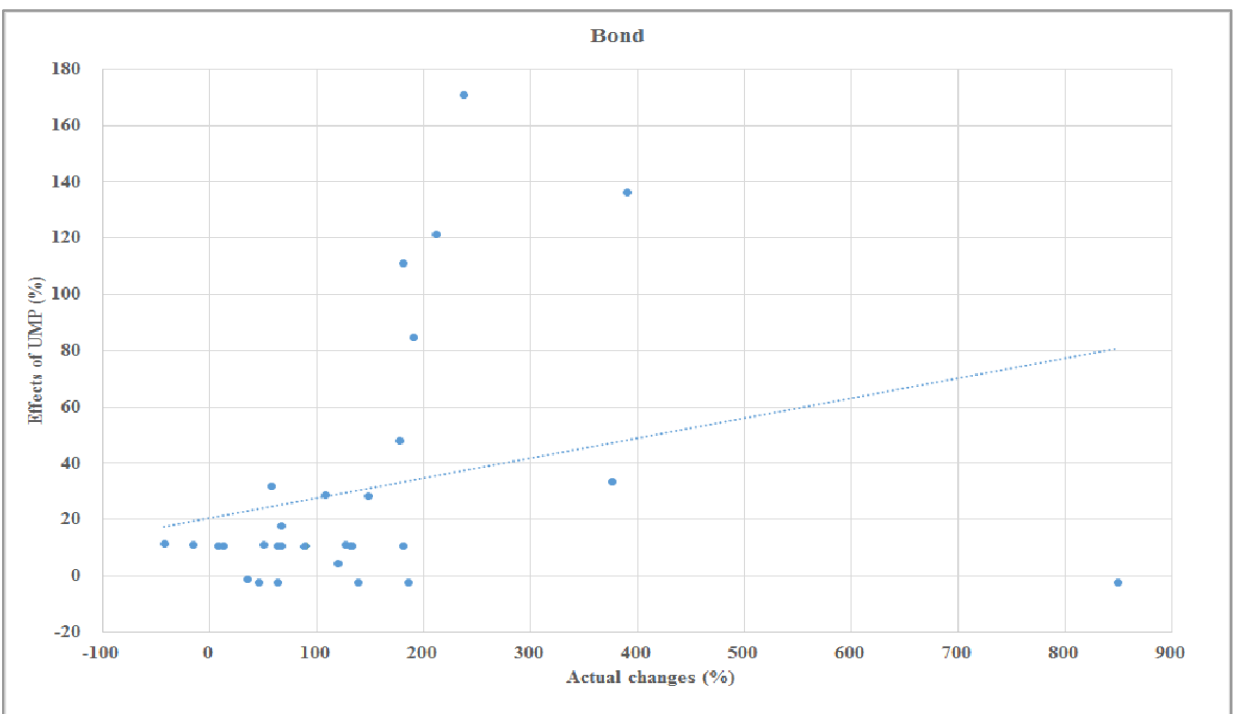

Note: The dotted line indicates the trend line. 
Figure 5: Actual Changes vs. The Effects of the UMP during the UMP Period: Equity-related CFs

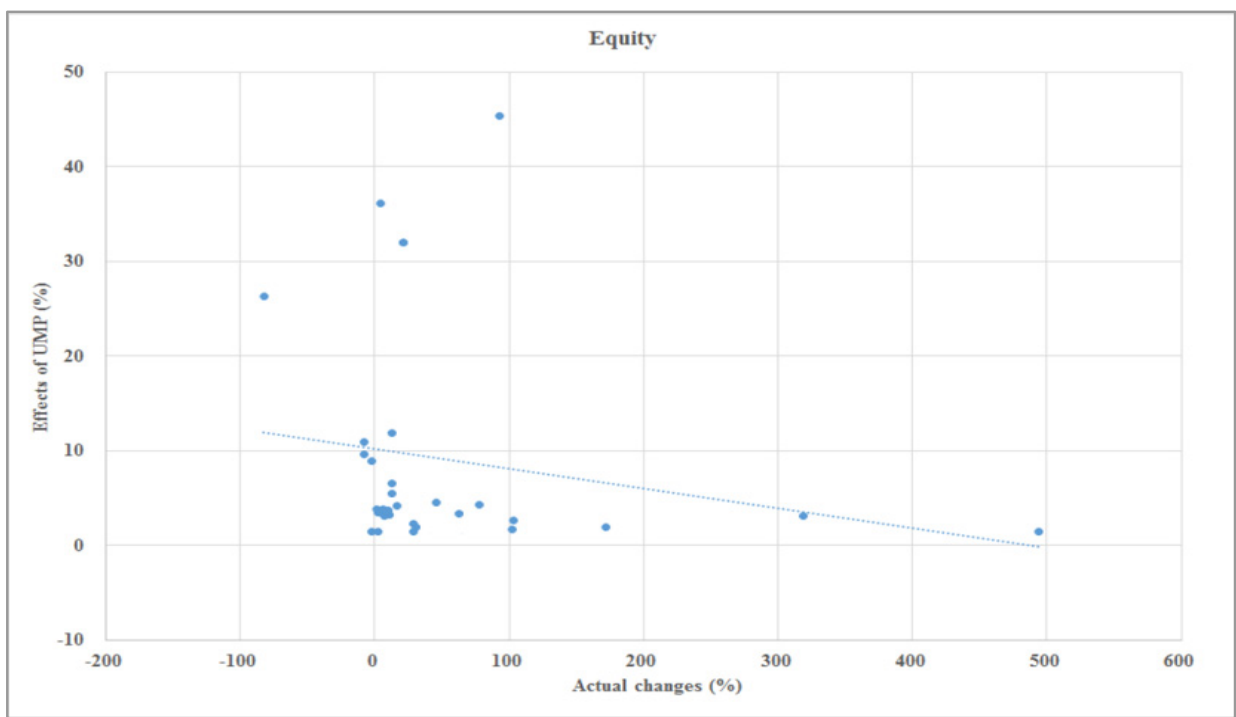

Note: The dotted line indicates the trend line.

effects of the UMP and the actual changes showed a slightly positive relationship and no relationship for the cases of bond and equity, respectively.

Allegedly, many EMEs employed macro-prudential policies against capital inflows during the UMP period. To examine the effectiveness of the macroprudential policies on CFs, we first classify countires employing the macro-prudential policies into two group the one employing strong policies and the other employing weak policies based on the macro-prudential policy index suggested by Cerutti, Claessens and Laeven (2015). We then show the actual capital flow changes, the UMP effects, and the difference between the two for each group in Figure 6 for the case of cross-border borrowings. The strong group was exposed to a greater pressure from the UMP than the weak one; the UMP effects were, on average, $113.9 \%$ for the strong group and $84.8 \%$ for the weak group. However, the actual capital flow changes were similar for both groups $32.3 \%$ for the strong group and $28.0 \%$ for the weak group. This fact implies that the greater the extent to which countries are exposed to capital inflow pressure, the stronger macro-prudential policies tend to be employed to restrain capital inflows, and this 
Figure 6: The Effects of Macro-prudential Policies during the UMP Period:

Cross-border

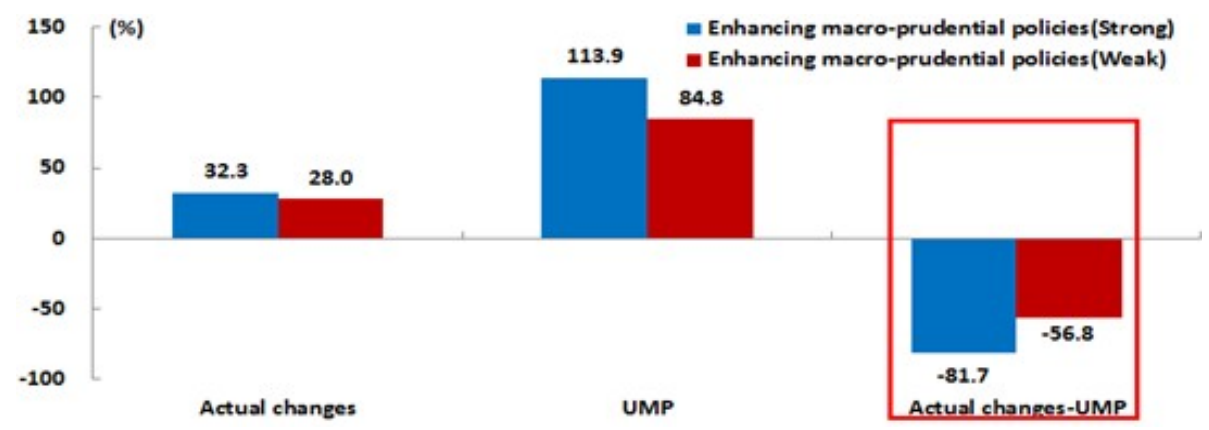

Notes: 1) The countries employing macro-prudential policies against capital inflows during the UMP period are classified into two groups, strong and weak, according to macro-prudential policy index suggested by Cerutti, Claessens and Laeven (2015).

2) This figure shows the actual capital flow changes, the UMP effects and the difference between the two for each group.

macro-prudential policy response proved its effectiveness. Interestingly, this fact is also true for bond-related and equity-related CFs even though the macroprudential policies during the UMP period were mainly employed to restrain capital inflows through cross-border borrowings. Figures 7 and 8 show the cases of bond-related and equity-related CFs, respectively.

\section{Effects of the normalization of the UMP}

To predict the effects of the normalization of the UMP, we need to construct a scenario for the normalization process. We assume that the normalization will proceed over three years. During the normalization period, the U.S. corporate spread is assumed to increase by 20 bps every quarter (i.e., 240 bps in total). In addition, the deviations from Taylor rule linearly adjust to zero over the normalization period.

Figures 9 to 11 show the effects of the normalization on borrowings, bond, and equity type CFs, compared to the effects of the UMP. In all cases, there exist close 
Figure 7: The Effects of Macro-prudential Policies during the UMP Period: Bond-related CFs

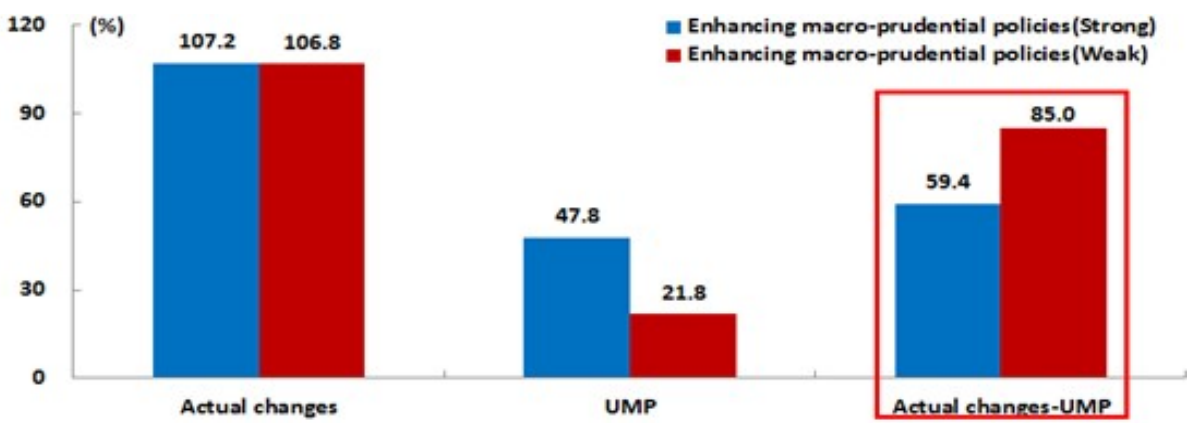

Notes: 1) The countries employing macro-prudential policies against capital inflows during the UMP period are classified into two groups, strong and weak, according to macro-prudential policy index suggested by Cerutti, Claessens and Laeven (2015).

2) This figure shows the actual capital flow changes, the UMP effects and the difference between the two for each group.

Figure 8: The Effects of Macro-prudential Policies during the UMP Period: Equity-related CFs

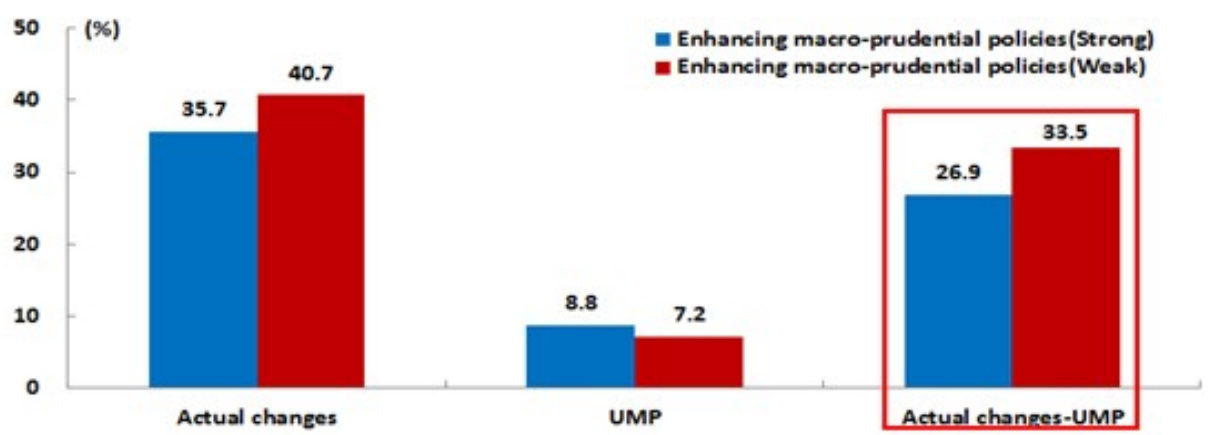

Notes: 1) The countries employing macro-prudential policies against capital inflows during the UMP period are classified into two groups, strong and weak, according to macro-prudential policy index suggested by Cerutti, Claessens and Laeven (2015).

2) This figure shows the actual capital flow changes, the UMP effects and the difference between the two for each group. 
Figure 9: The Effects of the UMP during the UMP Period vs. The

Normalization Effects of the UMP: Cross-border Borrowings

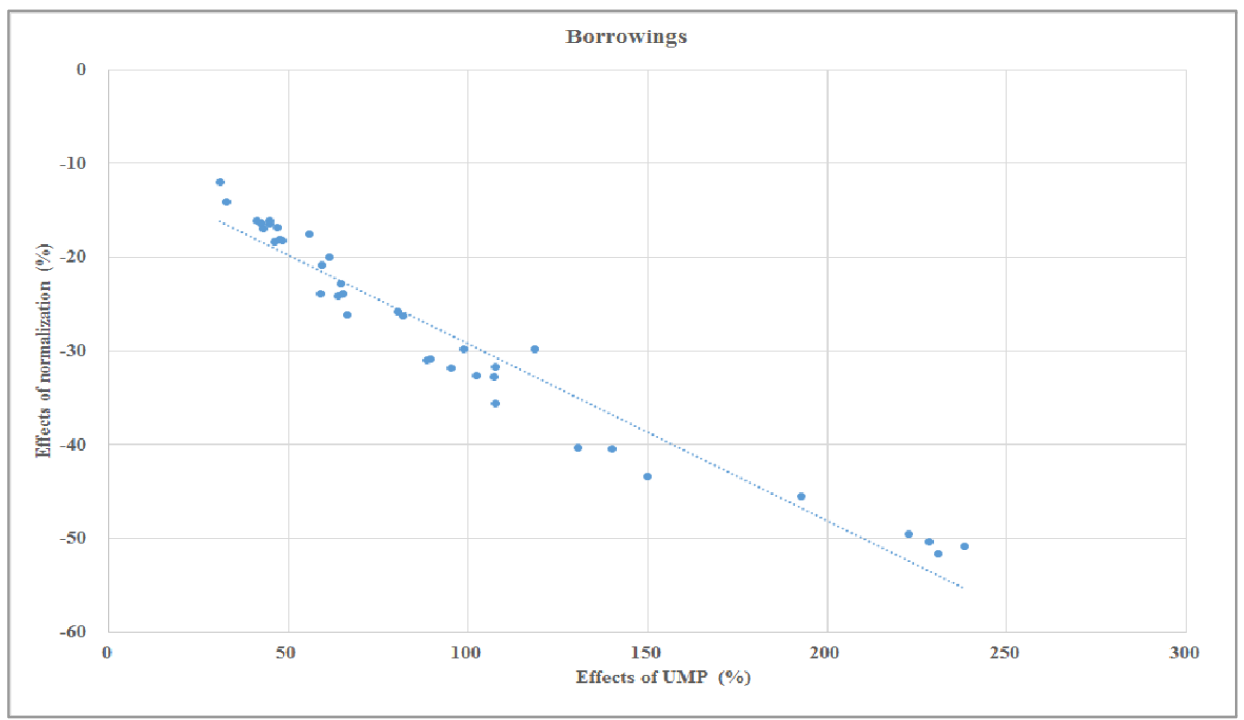

Note: The dotted line indicates the trend line.

Figure 10: The Effects of the UMP during the UMP Period vs. The Normalization Effects of the UMP: Bond-related CFs

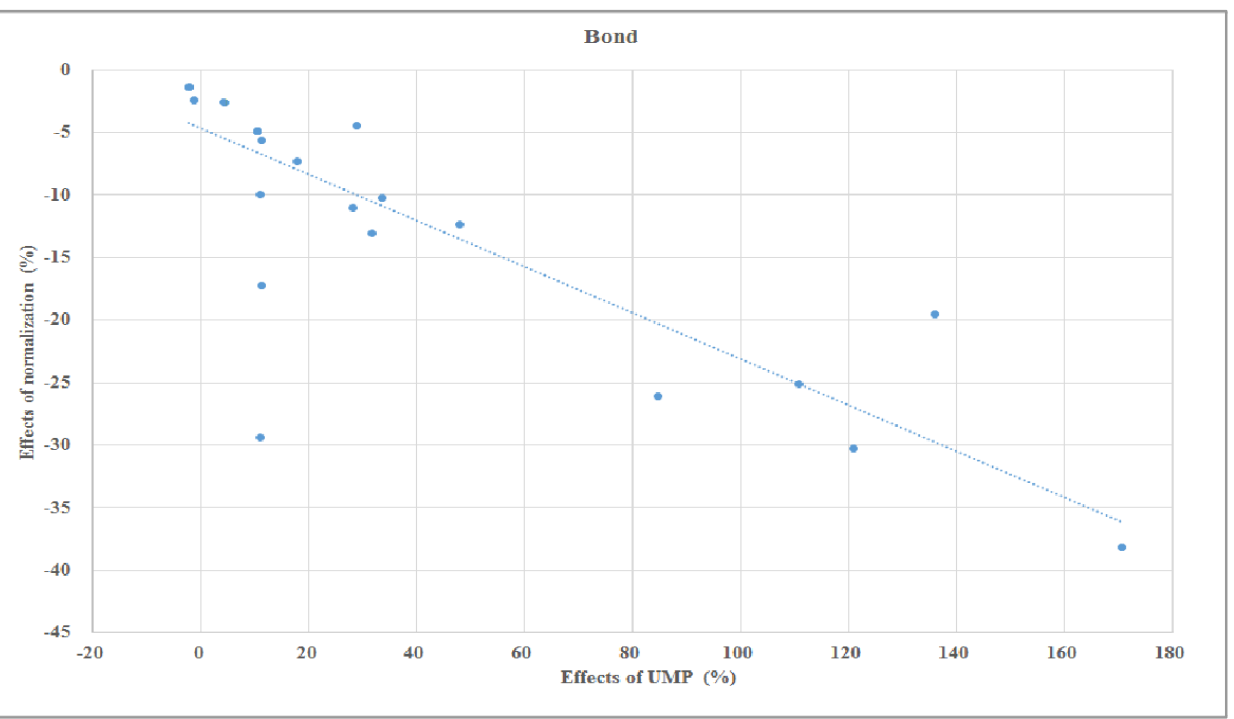

Note: The dotted line indicates the trend line. 
Figure 11: The Effects of the UMP during the UMP Period vs. The Normalization Effects of the UMP: Equity-related CFs

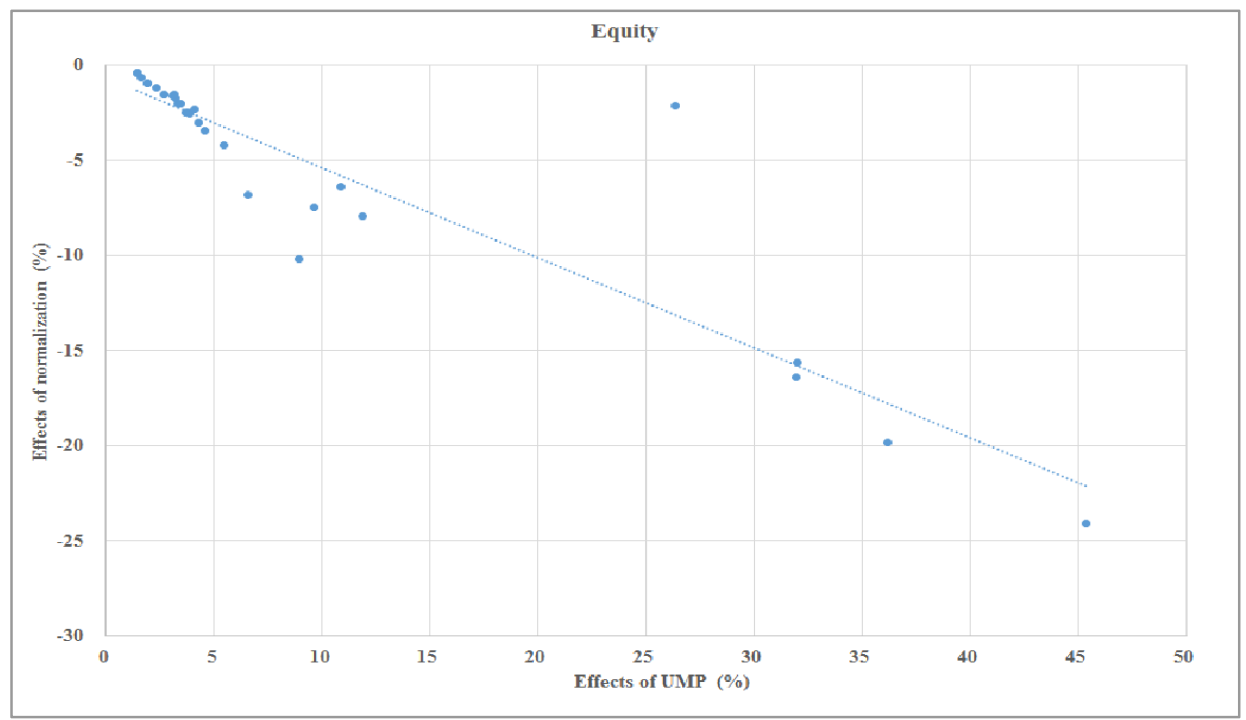

Note: The dotted line indicates the trend line.

negative relationships between the effects of the UMP and its normalization. The larger the UMP brings the capital inflows to EMEs, the larger the normalization takes the capital outflows from EMEs. This fact basically arises from our assumption about the normalization process which is close to a reversal of the UMP with a similar speed and size.

Large capital inflows into EMEs induced by the UMP may pose potential risks on the recipient economies, and the risks may materialize during a period of uncertainty such as the normalization period. This risk accumulation-burst process may make the UMP process and its normalization become asymmetric ones. To examine this concern, we try to see what happened during the TT period which lies between the past UMP period and the future normalization period. Figures 12 to 14 show the unexplained changes of CFs during the TT period, defined as the difference between the actual changes and the portions explained by actual movements of explanatory variables, which are contrasted with the effects of the UMP. For the case of borrowings, the larger the effects of the UMP, the larger the unexpected capital outflows during the TT period tend to be. This 
Figure 12: The Effects of the UMP during the UMP Period vs. The Unexplained Changes during the $\Pi$ Period: Cross-border Borrowings

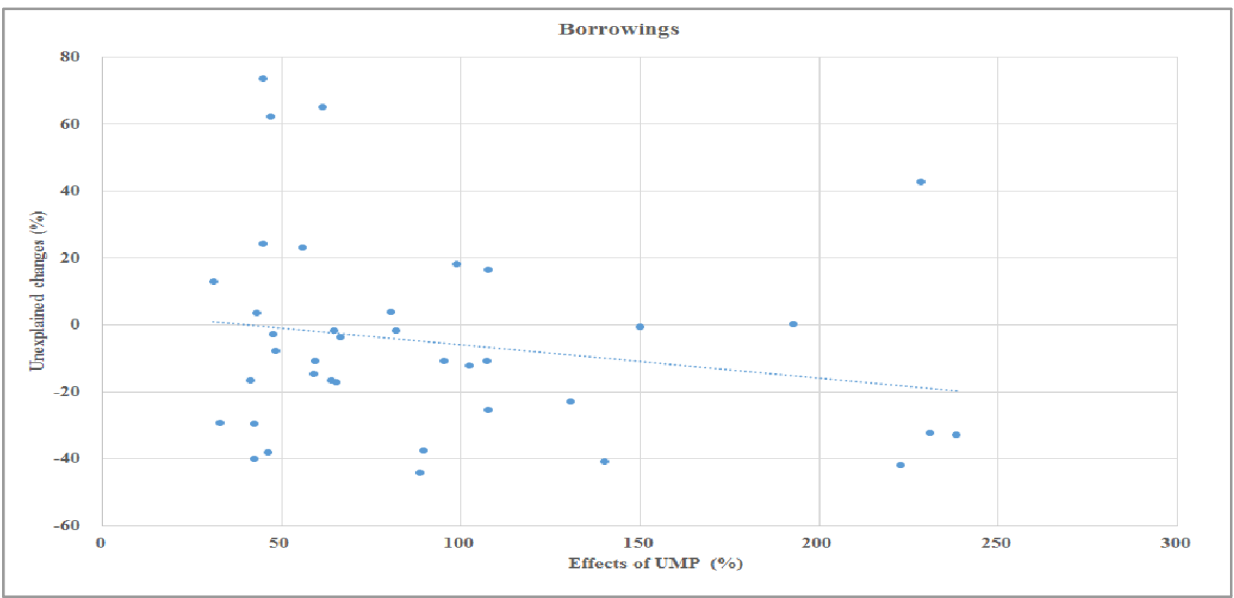

Notes: 1) The dotted line indicates the trend line.

2) The unexplained changes of Cross-border borrowings during the $\Pi$ period is the difference between the actual changes and the portions explained by actual movements of explanatory variables.

Figure 13: The Effects of the UMP during the UMP Period vs. The Unexplained Changes during the $\Pi T$ Period: Bond-related CFs

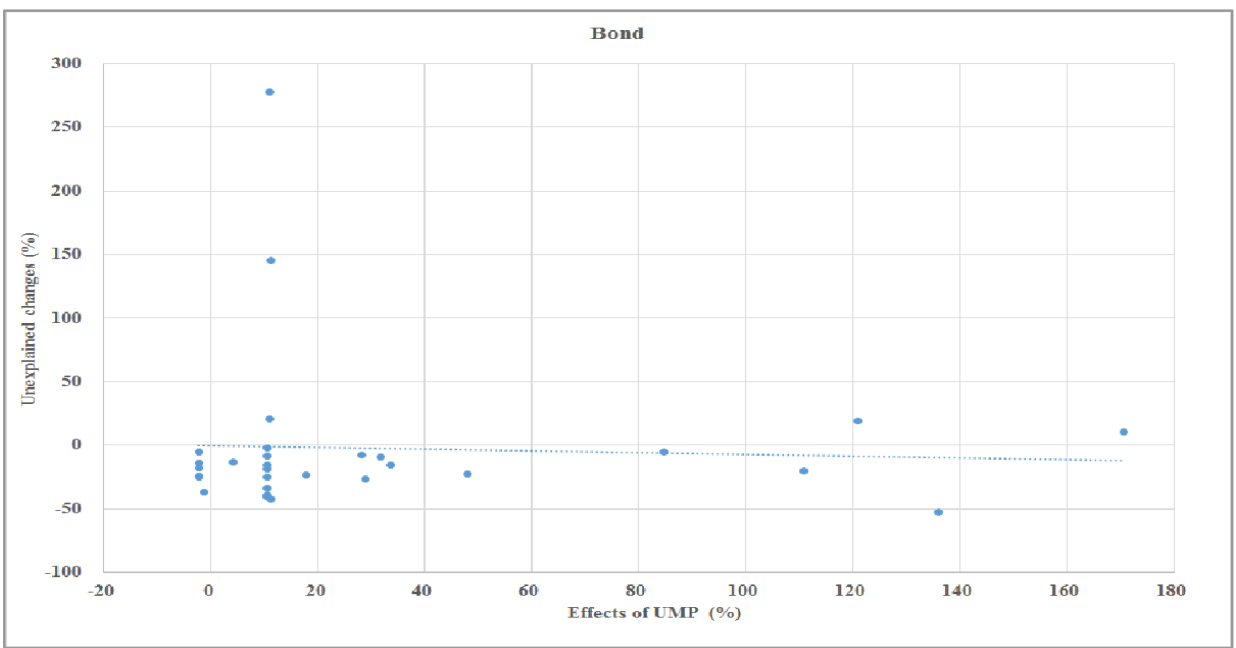

Notes: 1) The dotted line indicates the trend line.

2) The unexplained changes of bond-related CFs during the $\Pi$ period is the difference between the actual changes and the portions explained by actual movements of explanatory variables. 
Figure 14: The Effects of the UMP during the UMP Period vs. The Unexplained Changes during the $T$ Period: Equity-related CFs

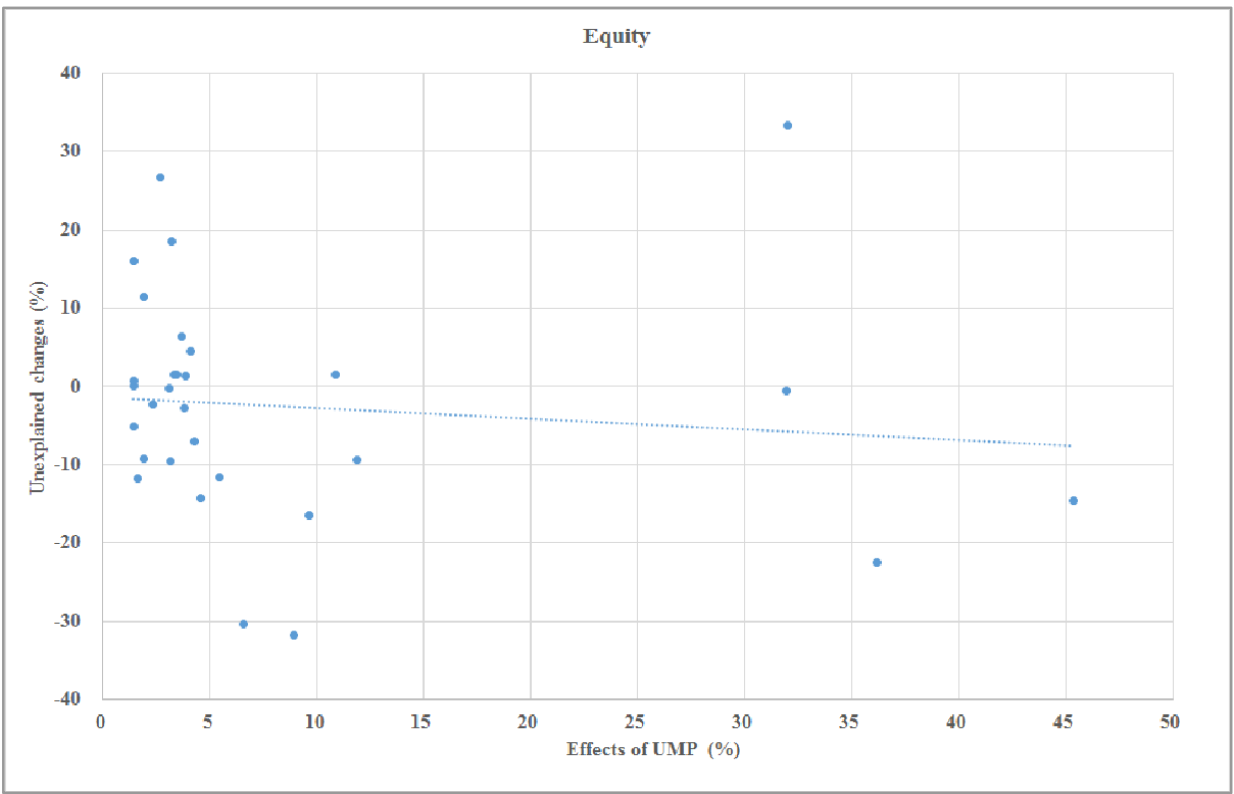

Notes: 1) The dotted line indicates the trend line.

2) The unexplained changes of equity-related CFs during the $\Pi$ period is the difference between the actual changes and the portions explained by actual movements of explanatory variables.

result has a profound policy implication. In addition to the predicted normalization effects, policy makers may need to take into account unexpected capital outflows during an uncertain period. Moreover, the size of unexpected capital outflows tends to be proportional to the size of the previous capital inflows.

Interestingly, this negative relationship between the unexpected capital outflows during the TT period and the effects of the UMP becomes unclear for the cases of bond and equity. One reason behind this difference might be related with the difference between bank loan contracts and capital market transactions. It typically takes time to adjust cross-border borrowings with a long-term loan contract while bond transactions can be made immediately in liquid capital markets. Therefore, this difference may make bank loan participants more sensitively respond to concerns over a future normalization of the UMP than capital market participants. 


\section{Robustness}

In this subsection, we investigate how sensitive our previous estimation results of the UMP effects and the normalization effects are to our benchmark assumptions. To this end, we set up alternative scenarios. For the UMP, we alternatively consider a "jump scenario" under which the U.S. corporate spread is assumed to jump down by 200 bps due to the UMP, following Chen, Filardo, He, Zhu (2015). For the normalization, we additionally consider "Fed scenario" for the deviations from Taylor rule.14) Figure 15 demonstrates various scenarios for the UMP and the normalization for each type of CFs. The jump UMP scenario for the U.S. credit spread would have greater impact than the benchmark one. On the other hand, the Fed normalization scenario for the deviations from Taylor rule would have less impact than the benchmark one.

Figure 16 shows the UMP effects under the jump scenario for cross-border borrowings (Panel A) and equity-related CFs (Panel B) against those under the benchmark scenario. Consistent with intuition, the jump scenario of the UMP has 1.42 times and 1.63 times more impacts on the borrowings and the equity-related CFs than the benchmark ones, respectively. On the other hand, the Fed scenario turns out to have less impact on the normalization than the benchmark one. As shown in Panels C, D, and E of Figure 13, the Fed scenario of the normalization has less impact than the benchmark one. The Fed scenario has impact only 0.55 , 0.39, 0.60 times of those of the benchmark for cross-border borrowings, bond-related CFs, and equity-related CFs, respectively.

\section{V . Conclusion}

In this paper, we quantitatively assess the effects of the UMP on CFs to EMEs and predict the effects of its normalization. We find that the effects of the UMP are sizable on average and vary across countries. The UMP affected CFs to EMEs greatly via both cross-border borrowings and bond channels but relatively little via

14) Refer to the Wall Street Journal article ("Fed Staffers Slightly Pessimistic About Economy's Course," July 24, 2015). 
Figure 15: Scenarios for the UMP and the Normalization
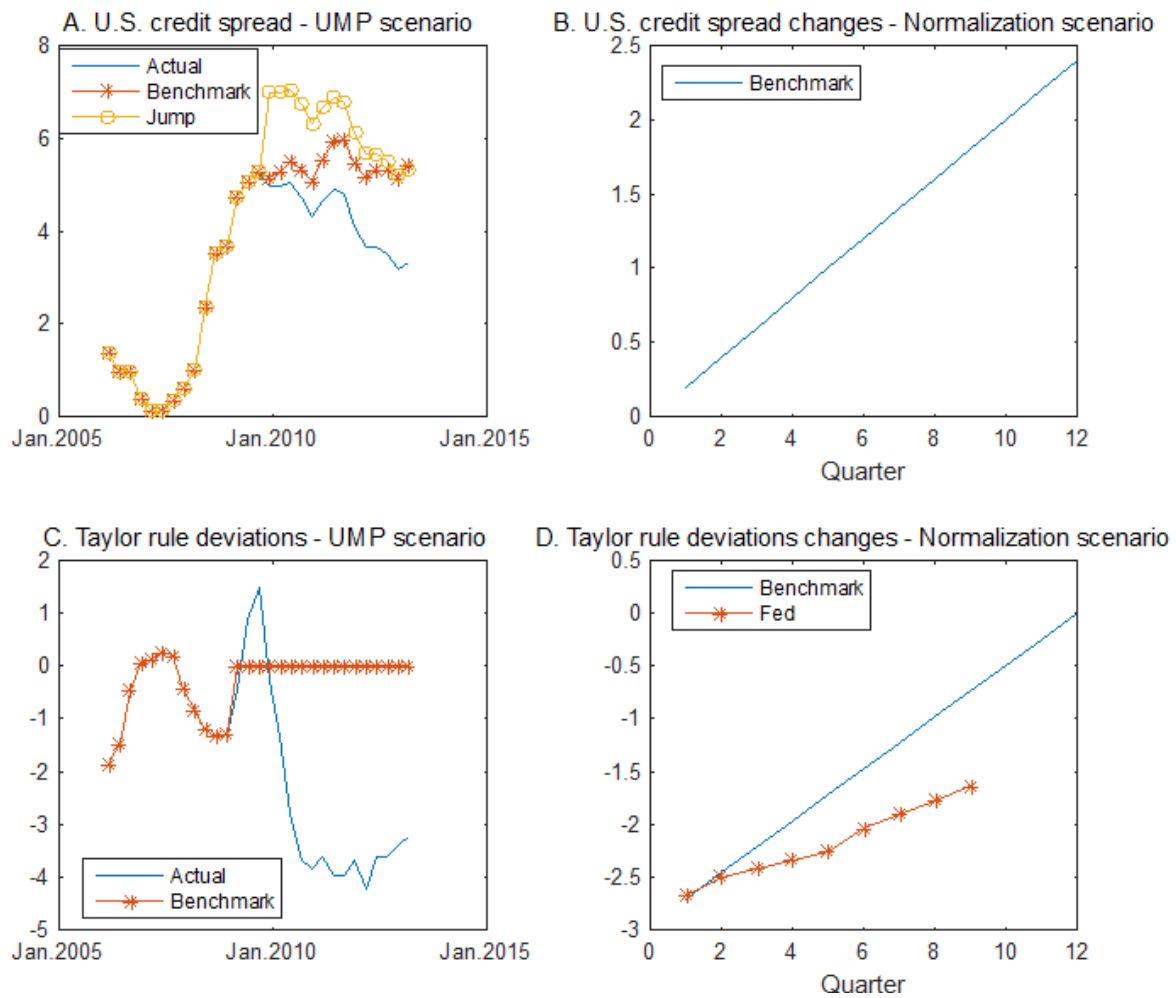

Notes: This figure shows scenarios for the UMP-related variables: the U.S. credit spread and the deviations from the Taylor rule.

equity channel. The effects of the normalization are closely related with the effects of the UMP. This finding has a policy implication. The larger the capital inflows due to the UMP, the larger the capital outflows due to the normalization. Moreover, policy makers need to take into account a potential risk of unexpected capital outflows (exceeding the expected ones) during an uncertain period whose size tends to be proportional to the size of the previous capital inflows.

Obviously, this analysis should be complemented in many directions to add more realism. It is better to use both this kind of cross-country analysis and individual country analyses instead of relying on only a single approach. It is also beneficial to include many important factors which are ignored in this analysis. One such factor is policy response. IMF (2013a) report that policy response 
Figure 16: Sensitivity of the UMP Effects and the Normalization Effects
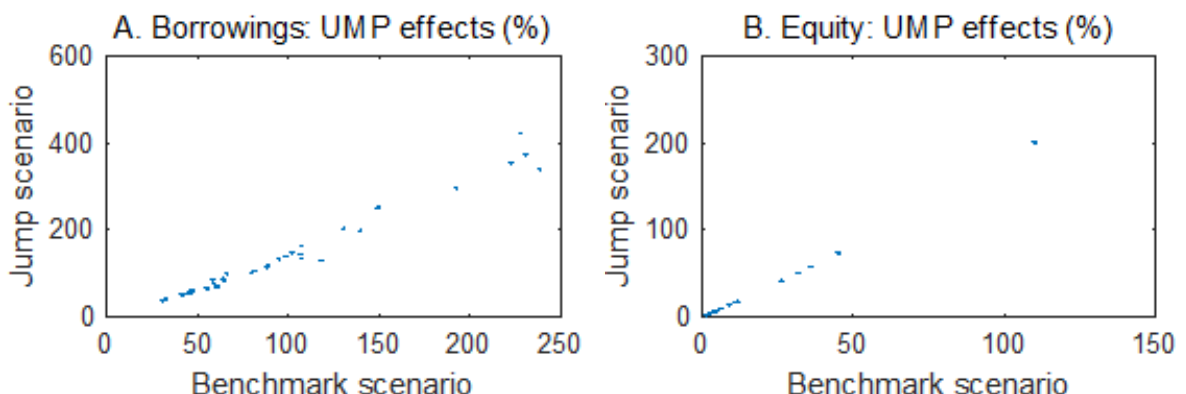

C. Borrowings: Normalization effects (\%)
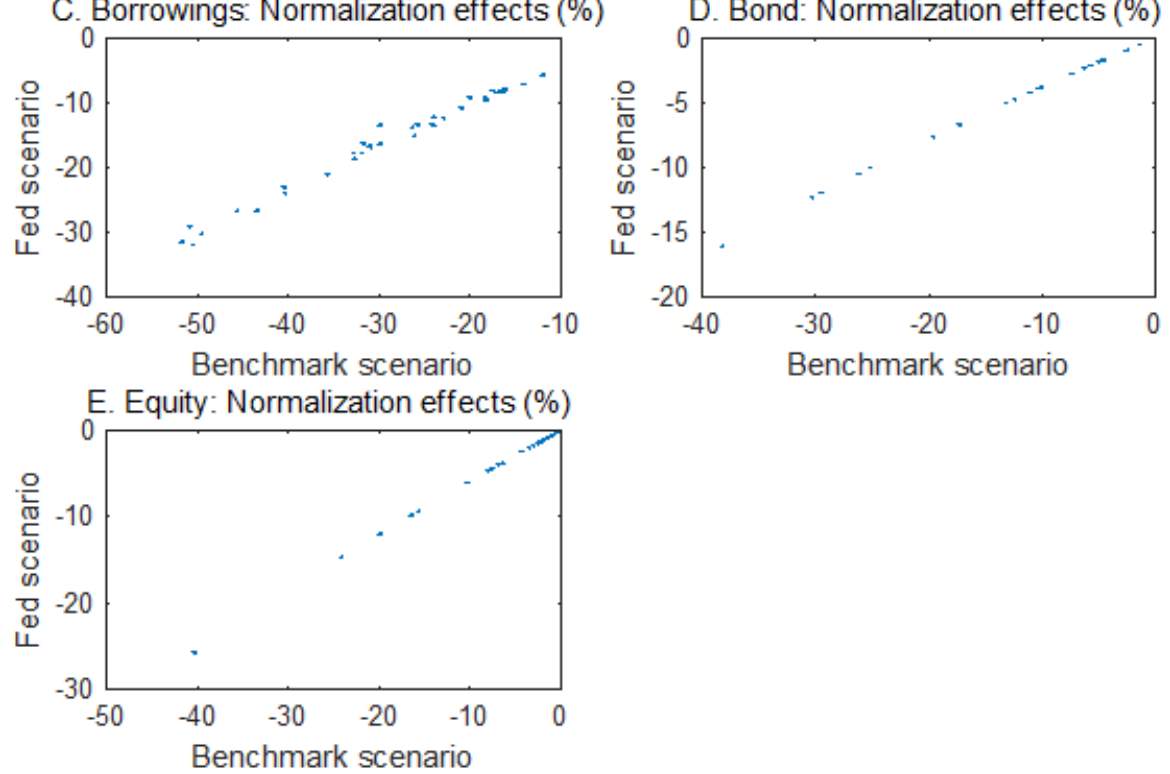

Notes: This figure shows a scatter plot of the UMP effects under the benchmark scenario and those under the jump scenario for cross-border borrowings (Panel A) and for equity-related CFs (Panel B) and scatter plots of the normalization effects under the benchmark scenario and those under the Fed scenario for cross-border borrowings (Panel C), for bond-related CFs (Panel D) and for equity-related CFs (Panel E).

matters during the UMP episode, and policy responses differ across countries. In addition, we may need to consider not only the U.S. policy stance but also those of other major economies such as the Eurozone, China, and Japan. The U.S. normalization policy may be offset by further UMPs by other economies or reinforced by a policy synchronization among them. 


\section{References}

Agosin, M. R., and F. Huaita (2012), "Overreaction in Capital Flows to Emerging Markets: Booms and Sudden Stops," Journal of International Money and Finance, Vol. 31, pp. 1140-1155.

Aizenman, J., Y. Jinjarak, and D. Park (2013), "Capital Flows and Economic Growth in the Era of Financial Integration and Crisis, 1990-2010," Open Economic Review, Vol. 24, pp. 371-396.

Arteta, C., B. Eichengreen, and C. Wyplosz (2001), "When Does Capital Account Liberalization Help More Than It Hurts?" NBER Working Paper, No. 8414 .

Avdjiev, S., and E. Takáts (2014), "Cross-border Borrowings during the Taper Tantrum: The Role of Emerging Market Fundamentals," BIS Quarterly Review, September 2014, pp. 49-60.

Bauer, M. D., and C. Neely (2014), "International Channels of the Fed's Unconventional Monetary Policy," Journal of International Money and Finance, Vol. 44, pp. 24-46.

BIS (2009), "Capital Flows and Emerging Market Economies,” CGFS Papers, No. 33.

Bruno, V., and H. S. Shin (2015), "Cross-border Banking and Global Liquidity," Review of Economic Studies, Vol. 82, pp. 535-564.

Caballero, J. A. (2014), "Do Surges in International Capital Inflows Infiuence the Likelihood of Banking Crises?” Economic Journal, doi: 10.1111/ecoj.12.172.

Cerutti, E., S. Claessens, and L. Laeven (2015), "The Use and Effectiveness of Macroprudential Policies: New Evidence," IMF Working Paper, WP15/61.

Chen, Q., A. Filardo, D. He, and F. Zhu (2015), "Financial Crisis, U.S. Unconventional Monetary Policy and International Spillovers," IMF Working Paper, WP15/85. 
Choong, C-K., A. Z. Baharumshah, Z. Yusop, and M. S. Habibullah (2010), "Private Capital Flows Stock Market and Economic Growth in Developed and Developing Countries: A Comparative Analysis," Japan and the World Economy, Vol. 22, pp. 107-117.

Diebold, F. X., and R. S. Mariano (1995), "Comparing Predictive Accuracy," Journal of Business and Economic Statistics, Vol. 13, pp. 253-263.

Eichengreen, B., and P. Gupta (2015), "Tapering Talk: The Impact of Expectations of Reduced Federal Reserve Security Purchases on Emerging Markets," Emerging Markets Review, doi:10.1016/j.ememar.2015.07.002.

Eichengreen, B. (2001), "Capital Account Liberalization: What Do Cross-country Studies Tell Us?" The World Bank Economic Review, Vol 16(3), pp. 41-365.

Fratzscher, M., M. L. Duca, and R. Straub (2013), "On the International Spillovers of U.S. Quantitative Easing,” ECB Working Paper, No. 1557.

Henry, P. B. (2007), "Capital Account Liberalization: Theory, Evidence, and Speculation," Journal of Economic Literature, Vol. 45, pp. 887-935.

IMF (2013), "Spillover Report - Analytical Underpinnings and Other Background," IMF Policy Paper, 2013a.

IMF (2013), "Global Impact and Challenges of Unconventional Monetary Policies," IMF Policy Paper, 2013b.

Koepke, R. (2013), "Quantifying the Fed's Impact on Capital Flows to Ems," IIF Research Note.

Koepke, R., (2015), "What Drives Capital Flows to Emerging Markets? A Survey of the Empirical Literature," Institute of International Finance Working Paper.

Kose, M. A., E. S. Prasad, K. Rogoff, and S-J. Wei (2009), "Financial Globalization: A Reappraisal,” IMF Staff Papers, Vol. 56(1), pp. 8-62. 
McCauley, R., P. McGuire, and V. Sushko (2015), "Global Dollar Credit: Links to U.S. Monetary Policy and leverage," Economic Policy, April 2015, pp. 187-229.

Neely, C. (2015), "Unconventional Monetary Policy Had Large International Effects," Journal of Banking and Finance, Vol. 52, pp. 101-111.

Reinhart, C. M., and V. R. Reinhart (2008), "Capital Flow Bonanzas: An Encompassing View of the Past and Present. In J. Frankel and F. Giavazzi (eds.)," NBER International Seminar in Macroeconomics 2008, Chicago, Chicago University Press for the NBER (2009), pp. 1-54.

Rey, H. (2013), "Dilemma Not Trilemma: The Global Financial Cycle and Monetary Policy Independence," Proceedings of the Federal Reserve Bank of Kansas City Jackson Hole Economic Symposium, Federal Reserve Bank of Kansas City, pp. 285-333.

Vo, X-V. (2010), "Net Private Capital Flows and Economic Growth - The Case of Emerging Asian Economics," Applied Economics, Vol. 42, pp. 3135-3146.

Yoon, K., and J. Kim (2015), "Costs of Foreign Capital Flows in Emerging Market Economies: Unexpected Economic Growth and Increased Financial Market Volatility," Bank of Korea Working Paper, 2015-21. 


\section{<Abstract in Korean>}

\section{미 연준의 비전통적 통화정책이 신흥국 자본유출입에 미치는 영향}

\section{서상원*, 구병수**}

본 연구는 미 연준의 비전통적 통화정책이 신흥국 자본유출입에 미치는 영향을 자본형태별 (은행차입, 채권 및 주식)로 구분하여 정량적으로 분석 하였다. 이와 함께 미 연준의 통화정책 정상화에 대한 시나리오를 기준으로 통화정책 정상화 시 신흥국의 자본유출 규모를 예측해보았다.

분석 결과, 미 연준의 비전통적 통화정책이 신흥국의 자본유입을 크게 증대 시켰던 것으로 분석되었다. 이와 함께 통화정책 정상화 시 국가별 자본유출 규모는 비전통적 통화정책으로 인한 자본유입 규모와 비례하는 것으로 나타 났다. 또한 비전통적 통화정책의 영향을 크게 받은 국가일수록 예상치 못한 자본유출이 발생할 가능성이 높은 것으로 추정되었다.

핵심주제어: 자본유출입, 비전통적 통화정책, 신흥국, 해외차입

JEL Classification: F37, F42, G15, G18

* 중앙대학교 경제학과 교수

** 한국은행 대구경북본부 조사역

이 연구내용은 집필자의 개인의견이며 한국은행의 공식견해와는 무관합니다. 따라서 본 논문의 내용을 보도 하거나 인용할 경우에는 집필자명을 반드시 명시하여 주시기 바랍니다. 